\section{Improving the ability to include freshwater wetland plants in process-based models}

\author{
A.S. Williams, D.M. Mushet, M. Lang, G.W. McCarty, J.A. Shaffer, S. Njambi Kahara, M.-V.V. John- \\ son, and J.R. Kiniry
}

\begin{abstract}
Considerable effort and resources have been placed into conservation programs designed to reduce or alleviate negative environmental effects of crop production and into evaluation of the benefits of these programs. Wetlands are an important source of ecosystem services, but modeling wetland plants is an emerging science. To date, wetland plant growth has not been explicitly accounted for in ecosystem service models that quantify conservation program effects. As part of an effort to more accurately simulate wetland plants within process-based models, we expanded upon plant growth data collected in an earlier effort with additional sampling at two of four previously sampled areas, and included a fifth sampling site. We then used data from the five sites spanning five years as wetland plant parameters at both the species and functional group levels for the Agricultural Land Management Alternative with Numerical Assessment Criteria (ALMANAC) model. In addition to individual species, modelers are interested in functional groups representing a collection of species because it is unrealistic to model every species occurring in an ecosystem. ALMANAC simulations were completed at three sites for both individual wetland plant species and functional groups. At each site, simulated plant yields were within $1 \mathrm{Mg} \mathrm{ha}^{-1}( \pm 7 \%)$ of measured values $\left(r^{2}=0.99\right)$. Multisite species simulated yields were within $37 \%$ of measured values $\left(r^{2}=0.95\right)$. Functional groups performed as well as individual species simulations. Functional group simulated yields were within $1 \mathrm{Mg} \mathrm{ha}^{-1}( \pm 5 \%)$ of measured yields. Plant growth is a major component of these wetland ecosystems, and ALMANAC verified wetland plant parameters support more accurate assessments of conservation programs and practices on the influence of wetland ecosystems embedded within agricultural fields. The improved plant parameters we provide here will be transferred to other process-based models that focus on other ecosystem components such as soil and water effects, facilitating wetland evaluations across the United States and elsewhere.
\end{abstract}

Key words: ALMANAC—-functional groups—-modeling — plants—wetlands

\begin{abstract}
Process-based wetland models and associated plant parameters are parts of a developing science, with constant improvements providing more accurate simulations of plant-growth influences on wetland hydrological, geochemical, and biological processes. Modeling wetlands is a vital necessity to inform landowners, conservationists, and policymakers of how ecosystem services provided by wetlands are affected by management activities and climatic influence. Wetlands provide numerous ecosystem services including aquifer recharge, floodwater and runoff mitigation, nutrient

and sediment trapping, biodiversity refugia, and human recreation (Brauman et al. 2007; Smith et al. 2015). Past research has focused on including upland species in process-based models. This past research on upland plants has facilitated great advances in modeling the effects of croplands and conservation practices (e.g., establishment of perennial vegetation buffers) on water dynamics within agricultural fields (Wang et al. 2006, 2008; Potter et al. 2006; Atwood et al. 2009; USDA NRCS 2014, 2018a). However, process-based model simulations of plant effects on fieldlevel hydrologic dynamics have been largely
\end{abstract}

Received May 28, 2019; Revised October 16, 2019; Accepted January 20, 2020. ignored in freshwater wetlands (natural and created). Wetland modeling has been primarily focused on hydrology, including the influence of upland land use and changes in climate (Rezaeianzadeh et al. 2018; PattisonWilliams et al. 2018; Matchett and Fleskes 2017; Sizo et al. 2015; Liu et al. 2018; Esralew et al. 2016). However, the few models that have focused on including wetland plants were either for coastal ecosystems (Visser and Duke-Sylvester 2017), or did not include plant growth (Voldseth et al. 2007; Wolski and Murray-Hudson 2008). A primary reason for this underrepresentation of wetlands in modeling efforts has been a dearth of information needed to parameterize models to accurately simulate the growth of wetland-specific plant species, or groups of wetland species. Accurate simulation of these plants is important for modeling water dynamics.

While agriculture is an obvious necessity for feeding growing world populations, government agencies need to address many of the practices associated with crop production that can have negative impacts on natural ecosystems. These negative impacts affect many services such as improved water quality and quantity (Gordon et al. 2010; Scanlon et al. 2005). Negative impacts of crop production include loss of habitat, sediment, nutrients, and pesticides, which result in erosion, runoff, and environmental contamination. The USDA funds numerous conservation programs designed to reduce or alleviate negative environmental effects of crop pro-

Amber S. Williams is a biological science technician, USDA Agricultural Research Service (ARS), Grassland, Soil and Water Research Laboratory, Temple, Texas. David M. Mushet is a research and wildlife biologist, US Geological Survey, Northern Prairie Wildlife Research Center, Jamestown, North Dakota. Megan Lang is chief scientist, US Fish and Wildlife Service, National Wetland Inventory, Falls Church, Virginia. Gregory W. McCarty is a research soil scientist, USDA ARS, Hydrology and Remote Sensing Laboratory, Beltsville, Maryland. Jill A. Shaffer is an ecologist, US Geological Survey, Northern Prairie Wildlife Research Center, Jamestown, North Dakota. Sharon Njambi Kahara is a research associate, Humboldt State University, Arcata, California. Mari-Vaughn V. Johnson is the director of the Pacific Islands Climate Adaptation Science Center, US Geological Survey, Manoa, Hawaii, formerly an agronomist, USDA Natural Resources Conservation Service, Temple, Texas. James $R$. Kiniry is a research agronomist, USDA ARS, Grassland, Soil and Water Research Laboratory, Temple, Texas. 
duction. The USDA's Conservation Effects Assessment Project (CEAP) was initiated with a goal of quantifying the environmental effects of conservation practices and programs (Johnson et al. 2015; Smith et al. 2015). This project provides guidance for conservation efforts to be more efficiently directed, and program-level cost/benefit ratios to be determined. Therefore, it is crucial for quantifications of the influence of conservation practices to be as accurate as possible.

CEAP-Wetlands was initiated as a new component of CEAP in 2004 (Smith et al. 2015). It has taken both a field research and modeling approach to determine the impacts of conservation practice implementation on ecosystem services provided by wetlands in agricultural lands. Field research enhances knowledge of environmental effects of specific practices, wetland processes, and data to develop process-based simulation model improvements. The models can then quantify how wetlands are integrated with the landscape, effects of agricultural conservation practices, and effects of changes in land use and climate. Since simulation modeling paired with field-based empirical studies is the primary means by which CEAP-Wetlands quantifies conservation effects, improving wetland models is crucial (Euliss Jr. et al. 2010).

Agricultural Land Management Alternative with Numerical Assessment Criteria (ALMANAC) is a process-based daily time-step plant growth model (Kiniry et al. 1992). This model has been used to simulate single plants and ecosystems, both in agricultural and native settings (Kiniry et al. 2007, 2013, 2017, 2018). ALMANAC simulates plant growth, senescence, competition, temperature response, stress, nutrient cycling, soil erosion, and hydrologic balance including infiltration, soil moisture, plant uptake, evapotranspiration, and runoff. Plant growth can be stressed by soil, water, nitrogen $(\mathrm{N})$, phosphorus $(\mathrm{P})$, temperature, salinity, and management practices. Various management practices, such as tillage and fertilization, can be applied. Once validated, the ALMANAC model's parameters can be transferred to other process-based models such as Environmental Policy Integrated Climate (EPIC), Agricultural Policy / Environmental eXtender (APEX), and Soil and Water Assessment Tool (SWAT) (Kim et al. 2018b; Meki et al. 2017, 2015; Chavez et al. 2018; Osorio et al. 2014). These mod-

\section{Figure 1}

Wetlands simulated from left to right are in California, North Dakota, and Delmarva. All five locations measured are shown below.
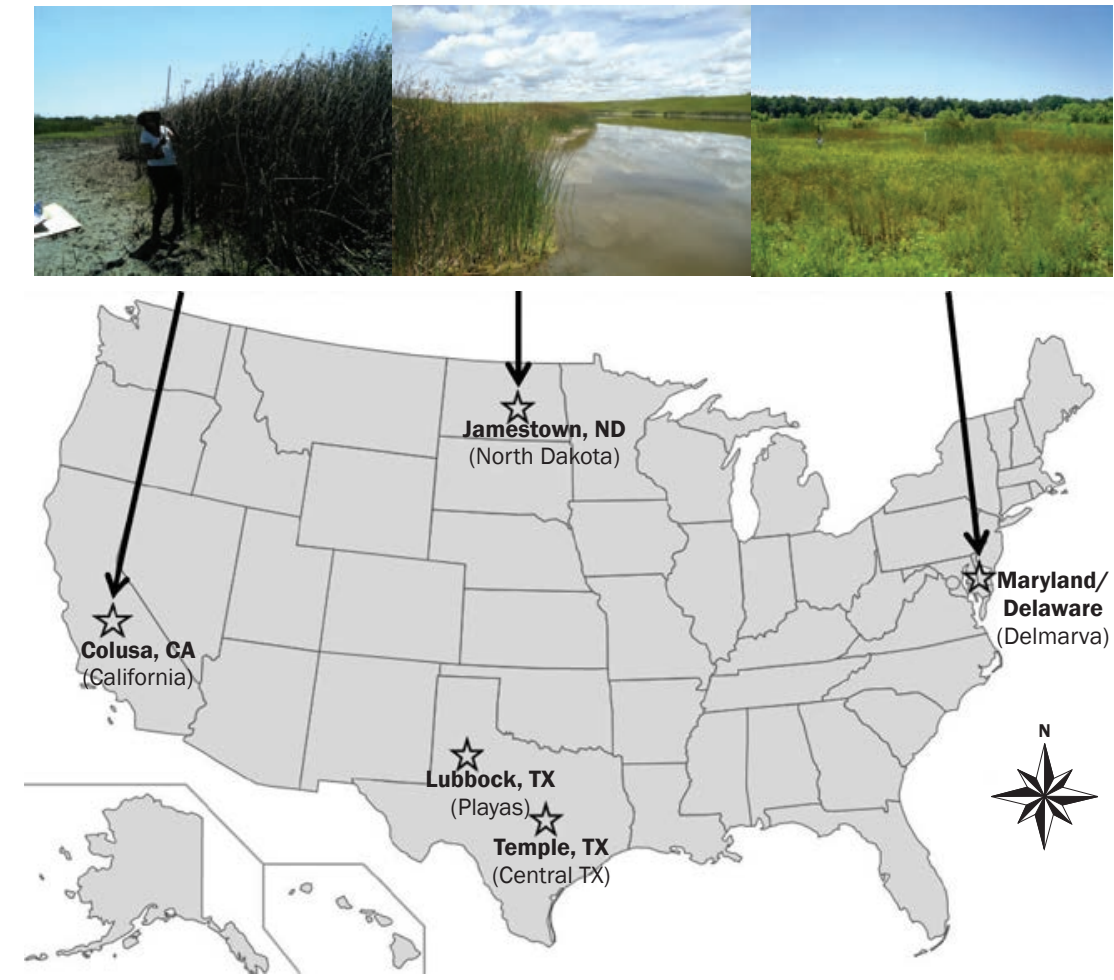

els focus on landscape- and watershed-scale simulations. This three step approach ([1] collecting plant data, [2] simulating local areas with ALMANAC, and [3] simulating regional areas with APEX/SWAT) has been implemented in other CEAP projects to help inform policy (Johnson et al. 2015) and will now be implemented for wetlands. This will fill the knowledge gap on wetland plant growth modeling, thus improving future endeavors addressing conservation effects on ecosystem services.

Regional wetland studies were established (Smith et al. 2015) to better ensure the CEAP-Wetlands goals were addressed throughout the nation. In an effort to more accurately simulate wetlands, we initiated a multiyear study to quantify plant-growth metrics specific to wetland species across multiple CEAP-Wetlands regions. The first phase of the work was conducted from 2013 to 2015 and determined wetland plant growth parameters from 18 species and two to four functional groups using data collected in four CEAP-Wetlands regions (Williams et al. 2017). Modeling every plant in every wetland nationwide is impractical.
Instead, functional groups have been used successfully in the past to represent similar situtations where it is not feasable to simulate every plant in an ecosystem (Boer and Stafford Smith 2003; Byun et al. 2013; Guo et al. 2015; Kiniry et al. 2013, 2014; Muler et al. 2018; Pokorny et al. 2005). In this study, wetland plant functional groups were determined based on plant growth habit and the measured plant parameter values as described below. Sites sampled in the initial effort were chosen from CEAP regions, and included the mid-Atlantic rolling plains of Delaware, Maryland, and Virginia peninsula (hereafter the study site is referred to as "Delmarva"), the Prairie Pothole Region (hereafter the study site is referred to as "North Dakota"), the Playa Region in southern High Plains of Texas, and central Texas (figure 1). The objectives in the current study were twofold: (1) to expand upon the plant growth data collected by Williams et al. (2017) by an additional two years of sampling at two of the previously sampled study sites (Delmarva and North Dakota) and at a new sampling site in a fifth CEAP-Wetlands region, the California Central Valley (hereafter the study 
site is referred to as "California") including new measurements of radiation use efficiency, seed weight, and harvest index; and (2) to use the enhanced data set to simulate both individual species and functional groups in ALMANAC at the field sites.

\section{Materials and Methods}

Field Data. We sampled plant growth parameters at the Delmarva, North Dakota, and California sites (figure 1) over the 2016 to 2017 growing seasons. Delmarva and North Dakota are depressional wetlands; neither were planted, fertilized, or hydrologically managed during the study. For more details on the Delmarva and North Dakota sites, including the species sampled, refer to Williams et al. (2017). The newly added California site was located on the Colusa National Wildlife Refuge in Colusa, California. Unlike the other wetlands in this and the previous study, which were naturally occurring depressional wetlands, the wetlands sampled in California were created by dikes in historic floodplains, and water inflows and outflows were heavily managed. Water from irrigation ditches was allowed to flood the wetland at certain times of the year, then later drained to dry the wetland (US Fish and Wildlife Service 2009; Smith et al. 1995). Empirical information regarding inundation periodicity and depth was unavailable, but refuge managers mimicked natural flooding cycles as stated in their management plan (US Fish and Wildlife Service 2009; Smith et al. 1995). The California species sampled and their wetland indicator status (USDA NRCS 2018b) include joint grass (Paspalum distichum; facultative wetland), alkaline bulrush (Scirpus maritimus; obligate wetland), swamp timothy (Crypsis schoenoides; obligate wetland), annual smartweed (Persicaria lapathifolium; facultative wetland), watergrass (Echinochloa crus-galli; facultative), cattail (Typha spp.; obligate wetland), spikerush (Eleocharis spp.; includes both facultative wetland and obligate wetland species), and rabbitsfoot (Polypogon monspeliensis; facultative wetland).

Plant parameter data collected for the models included fraction of intercepted photosynthetically active radiation (FIPAR), leaf-area index (LAI), light extinction coefficient $(k)$, radiation use efficiency (RUE), plant height, dry weight, seed weight, harvest index $(\mathrm{HI})$, and nutrient values for $\mathrm{N}$ and P. FIPAR was measured using a cep-

\section{Table 1}

Experimental locations, nearest weather stations' latitude and longitude, and the wetland soil type. Due to privacy agreements, specific site latitude and longitude cannot be divulged, but the coordinates listed are the weather stations used in the simulations. Soil types shown occur at field site locations and were used for simulations.

\begin{tabular}{lll}
\hline Location & $\begin{array}{l}\text { Weather station's } \\
\text { latitude, longitude }\end{array}$ & Soil type for vegetation \\
\hline North Dakota & $46.9258,-98.6691$ & Parnell silty clay loam, 0\% to 1\% slopes \\
Delmarva & $39.1733,-76.683$ & Corsica mucky loam, 0\% to 1\% slopes \\
California & $39.1875,-122.0269$ & Willows silty clay, 0\% to 1\% slopes, frequently flooded
\end{tabular}

tometer, LAI was quantified using a leaf area meter and the ground area sampled, and $k$ was determined from the LAI and FIPAR according to Beer's law (Monsi and Saeki 1953). RUE, while not collected in the previous study, was calculated here as the increase in aboveground dry biomass per summed unit of intercepted photosynthetically active radiation. RUE values for a single species were based on the 2016 to 2017 data, which showed an increase in dry weight over the growing season. Plant height was measured from the ground or water to the tip of the tallest plant to help determine maximum potential growth. Aboveground dry weights and seed weights were recorded to compare to simulated yields and calculate other parameters including LAI, $k$, RUE, and HI. Seed weight, HI, and RUE were only determined in 2016 to 2017. Nutrient values were derived from vegetation across three harvests throughout the growing season. These were quantified separately for each plant part (stems, leaves, and reproductive parts). Phosphorus values were collected in 2015 to 2016, and N values were sampled in 2017. Nutrient concentrations in vegetation for 2015 to 2017 were determined from ground dry plant matter using the inductively coupled plasma atomic emission spectrometry (ICP-AES) technique (Isaac et al. 1998). For additional details regarding the field sampling procedures, refer to Williams et al. (2017).

ALMANAC Simulations. Three sites, Delmarva, North Dakota, and California, were simulated in ALMANAC based on the 2013 to 2017 data applicable to each site. Site coordinates used in the simulations matched the physical sampling sites but cannot be shared here due to privacy agreements. Weather data used for our simulations were downloaded from weather stations nearest to each site during the sampling years from the National Oceanic and Atmospheric Administration (NOAA)'s Climate Data Online website (NOAA 2018). Soil Survey
Geographic Database (SSURGO) data were downloaded from USDA Natural Resources Conservation Service (NRCS)'s Web Soil Survey website (USDA NRCS 2018c). The nearest weather station coordinates, and soils at Delmarva, North Dakota, and California, are listed in table 1.

In the model simulations, management was kept consistent at each site. Simulations for all sites had the target species planted in Year One on April 2, and harvested on August 1. These dates were chosen as an average date across all sites based on the measured plant greenup dates and the final field harvest dates. To mimic the ideal unstressed growing conditions, we used the ALMANAC automatic irrigation and automatic fertilization functions. ALMANAC was set to irrigate using furrows so the water would pool on the surface. Auto irrigation added more water when the plant water stress reached a user-defined value. Auto fertilization added more $\mathrm{N}$ when the plant $\mathrm{N}$ stress factor reached 0.99 day. Maximum yearly automatic fertilization applied was adjusted for each of the sites: $200 \mathrm{~kg} \mathrm{ha}^{-1} \mathrm{~N}$ for North Dakota, $100 \mathrm{~kg}$ $\mathrm{ha}^{-1} \mathrm{~N}$ for Delmarva, and $300 \mathrm{~kg} \mathrm{ha}^{-1} \mathrm{~N}$ for California. At the field sites, only California actually had water management applied by managers. As we did not have access to that information, we assumed that the introduced irrigation water had higher nutrients entering the system than the other rainfed sites, hence the higher applied $\mathrm{N}$.

Plant growth parameters were derived from the initial four locations from 2013 to 2015 (Williams et al.2017) and supplemented with the additional data collected from Delmarva, North Dakota, and California from 2016 to 2017. Simulations were then run at the final three sites spanning the entire data collection years for the pertinent species at each site and compared to actual plant growth field data. Four wetland plant species were not simulated from these sites due to insufficient data. In California smartweed, 
Table 2

Average values for plant functional group parameters used in models of plant growth collected from wetlands in California, North Dakota, Texas, and the Delaware, Maryland, and Virginia peninsula, 2013 to 2017. FIPAR is the fraction of intercepted photosynthetically active radiation. Max LAI is the maximum leaf area index. $k$ is the extinction coefficient. Dry Wt is the total aboveground plant dry weight. Seed Wt is the seed weight. $\mathrm{HI}$ is the harvest index. RUE is the radiation use efficiency. Seed Wt and RUE were measured only in 2016 and 2017.

\begin{tabular}{|c|c|c|c|c|c|c|c|}
\hline Wetland species & FIPAR & Max LAI & k & $\begin{array}{l}\text { Dry Wt } \\
\left(\mathrm{g} \mathrm{m}^{-2}\right)\end{array}$ & $\begin{array}{l}\text { Seed Wt } \\
\left(\mathrm{g} \mathrm{m}^{-2}\right)\end{array}$ & HI & $\begin{array}{l}\text { RUE } \\
\left(g^{-2} \mathrm{~J}^{-2}\right)\end{array}$ \\
\hline \multicolumn{8}{|l|}{ Rushes and sedges } \\
\hline Spikerush (Eleocharis spp.) & 0.24 & 0.88 & -0.29 & 387.3 & 123.3 & 0.17 & - \\
\hline Bulrush (Schoenoplectus spp.) & 0.40 & 1.45 & -0.80 & 405.7 & 75.0 & 0.13 & 2.541 \\
\hline Poverty rush (Juncus tenuis) & 0.46 & 4.31 & -0.48 & 687.8 & 63.6 & 0.16 & 9.601 \\
\hline Average & 0.41 & 1.91 & -0.76 & 384.6 & 73.7 & 0.19 & - \\
\hline Standard deviation & 0.17 & 1.48 & 0.38 & 210.0 & 37.5 & 0.07 & - \\
\hline \multicolumn{8}{|l|}{ Forbs } \\
\hline Bur ragweed (Ambrosia grayi) & 0.31 & 0.55 & -0.63 & 94.2 & - & - & - \\
\hline $\begin{array}{l}\text { Narrowleaf goosefoot } \\
\text { (Chenopodium leptophyllum) }\end{array}$ & 0.70 & 1.88 & -0.66 & 460.8 & - & - & - \\
\hline Cattail (Typha spp.) & 0.52 & 2.67 & -0.70 & 895.2 & 200.7 & 0.20 & 4.096 \\
\hline Average & 0.45 & 1.38 & -0.70 & 316.1 & 103.6 & 0.11 & - \\
\hline Standard deviation & 0.17 & 0.85 & 0.23 & 320.8 & 137.3 & 0.12 & - \\
\hline \multicolumn{8}{|l|}{ Grasses } \\
\hline $\begin{array}{l}\text { Rabbitsfoot (Polypogon } \\
\text { monspeliensis) }\end{array}$ & 0.26 & 1.55 & -0.25 & 342.4 & 187.4 & 0.55 & - \\
\hline Sprangletop (Scolochloa festucacea) & 0.62 & 1.61 & -1.26 & 322.8 & 47.8 & 0.07 & 2.135 \\
\hline Watergrass (Echinochloa crus-galli) & 0.56 & 2.65 & -0.55 & 773.9 & 103.6 & 0.11 & 0.789 \\
\hline $\begin{array}{l}\text { Reed canarygrass } \\
\text { (Phalaris arundinacea) }\end{array}$ & 0.74 & 2.84 & -0.75 & 507.5 & 63.7 & 0.12 & 1.177 \\
\hline
\end{tabular}

rabbitsfoot, and spikerush were not simulated, whereas in North Dakota, slough sedge (Carex atherodes) was not simulated. Reed canarygrass (Phalaris arundinacea) had three parameter values determined from Schilling and Kiniry (2007): the fraction of the season when leaf area declines, and the minimum and maximum growing temperatures. Plant parameters derived for the simulations were radiation use efficiency for the model calculated as RUE times 10 as a unit conversion factor (WA), harvest index (HI), maximum growing temperature in ${ }^{\circ} \mathrm{C}(\mathrm{TB})$, minimum growing temperature in ${ }^{\circ} \mathrm{C}(\mathrm{TG})$, maximum LAI (DMLA), fraction of growing season when leaf area declines (DLAI), first point on leaf area development curve (LAP1), second point (LAP2), plant population at a low density with a fraction of LAI (PPL1), higher density (PPL2), rate of decline in WA (RBMD), maximum plant height in meters (HMX), maximum root depth in meters (RDMX), extinction coefficient from Beer's law $(k)$, plant population per $1 \mathrm{~m}^{2}(\mathrm{POP})$, and potential heat units (PHU).

Single species were simulated first to establish parameters, followed by functional groups. Species omitted from simulation runs were those that did not show an increase in dry weight, were not sampled frequently enough, or did not have reproductive parts during the sampling period. In Williams et al. (2017) we used a different approach to create functional groups: high LAI versus low LAI, or all rushes/sedges versus other forbs versus grasses. With the addition of more field data, our high and low LAI groups changed slightly. We added more grasses and bulrush changed functional groups from the low LAI group to the high LAI group. Since we did not simulate any from the low LAI group except marsh flatsedge (Cyperus pseudovegetus) at Delmarva, the group split is not shown for any low/high LAI groupings. Functional groups were (1) rushes and sedges, (2) forbs, and (3) grasses.

\section{Results and Discussion}

Field Data. Field data gathered in 2013 to 2015 were updated with 2016 to 2017 values, and new variables such as HI and RUE 
were determined (table 2). Field measured values from all our wetland plant species from all five field sites and from all five years are arranged according to their functional group. The forbs functional group had the lowest HI (0.11). This group had the highest seed weight measured $\left(103.6 \mathrm{~g} \mathrm{~m}^{-2}\right)$ due to the inclusion of cattail $\left(200.7 \mathrm{~g} \mathrm{~m}^{-2}\right)$. As more values for seed weight are collected for this functional group in the future, it may not remain the highest as there were many grasses with a high seed weight (average $99.4 \mathrm{~g} \mathrm{~m}^{-2}$ ). The grasses functional group had the highest values for FIPAR (0.65), LAI (2.92), and dry weight (506.8 $\mathrm{g} \mathrm{m}^{-2}$ ). Variation of field data is expected in natural systems. Cattail dry weights ranged from 110 to $1,605 \mathrm{~g} \mathrm{~m}^{-2}$, but the additional data helped give stability to our averages (table 3 ). Dry weights were not previously published and are incorporated in table 3 along with seed weight and HI. Nutrient values showed a general decrease across the season, with a few exceptions (table 4). Cattail and smartweed did not follow these trends, possibly because these species tend to start growing later in the season than the other plants in the study and thus would also have persisted later in the season before seeing a decline in nutrient values. Smartweed, for example, was often green but still submerged when the other plants were already above water level for measuring. When these two species were harvested early

Table 3

Average values for plant dry weight (Dry Wt), seed weight (Seed Wt), and harvest index (HI) collected from wetlands in Texas; North Dakota; the Delaware, Maryland, and Virginia peninsula (Delmarva); and California, 2013 to 2017. If many sites per location, we took the result from each site, then averaged them to get the location result. Dry weight was obtained from the last harvest of the year unless there were unusual circumstances. Seed weight was from the date with the highest seed weight. All values are in $\mathrm{g} \mathrm{m}^{-2}$ except $\mathrm{HI}$, which is unitless.

\begin{tabular}{|c|c|c|c|c|c|c|c|c|c|c|c|c|}
\hline \multirow[b]{2}{*}{ Location and species } & \multirow{2}{*}{$\frac{2013}{\text { Dry Wt }}$} & \multirow{2}{*}{$\frac{2014}{\text { Dry Wt }}$} & \multirow{2}{*}{$\frac{2015}{\text { Dry Wt }}$} & \multicolumn{3}{|l|}{2016} & \multicolumn{3}{|l|}{2017} & \multicolumn{3}{|c|}{ Average across all years } \\
\hline & & & & Dry Wt & Seed Wt & HI & Dry Wt & Seed Wt & HI & Dry Wt & Seed Wt & HI \\
\hline \multicolumn{13}{|l|}{ Lubbock, Texas } \\
\hline Narrowleaf goosefoot & 460.8 & - & - & - & - & - & - & - & - & 460.8 & - & - \\
\hline Spikerush & 77.0 & 2.2 & - & - & - & - & - & - & - & 39.6 & - & - \\
\hline \multicolumn{13}{|l|}{ Temple, Texas } \\
\hline Arrowhead/duck potato & - & 26.8 & 116.3 & - & - & - & - & - & - & 71.5 & - & - \\
\hline Black willow & - & 320.3 & - & - & - & - & - & - & - & 320.3 & - & - \\
\hline Hardstem bulrush & - & 130.5 & - & - & - & - & - & - & - & 130.5 & - & - \\
\hline \multicolumn{13}{|l|}{ Jamestown, North Dakota } \\
\hline Narrowleaf cattail & - & 661.1 & 110.0 & $1,045.6$ & 259.9 & 0.25 & 978.8 & 138.0 & 0.14 & 698.9 & 198.9 & 0.19 \\
\hline Slough sedge & - & 593.5 & 229.0 & 260.5 & - & - & 297.6 & - & - & 345.1 & & \\
\hline Sprangletop & - & 133.1 & 193.1 & 534.1 & - & - & 430.8 & $47.8 *$ & $0.07 *$ & 322.8 & 47.8 & 0.07 \\
\hline \multicolumn{13}{|l|}{ Delmarva } \\
\hline Broadleaf cattail & - & 839.3 & 517.0 & 512.9 & $88.7 *$ & $0.22 *$ & 514.3 & $139.6^{*}$ & $0.17 *$ & 595.9 & 114.2 & 0.19 \\
\hline Poverty rush & - & $1,101.2$ & 857.8 & 340.4 & $67.5 *$ & $0.11 *$ & 451.7 & $59.8^{*}$ & $0.22 *$ & 687.8 & 63.6 & 0.16 \\
\hline Pink smartweed & - & 236.6 & 321.9 & 247.5 & 17.3 & 0.06 & 36.7 & 2.1 & 0.03 & 210.7 & 9.7 & 0.05 \\
\hline Marsh flatsedge & - & 140.3 & 83.6 & 65.3 & $59.8 *$ & $0.55 *$ & 100.2 & $72.0 *$ & $0.64 *$ & 97.3 & 65.9 & 0.59 \\
\hline \multicolumn{13}{|l|}{ Colusa, California } \\
\hline Joint grass & - & - & - & 475.1 & $74.3 *$ & $0.11 *$ & 418.1 & 16.9 & 0.04 & 446.6 & 45.6 & 0.07 \\
\hline Alkaline bulrush & - & - & - & 880.1 & 57.9 & 0.05 & 442.6 & 110.5 & 0.24 & 661.4 & 84.2 & 0.14 \\
\hline
\end{tabular}

*Dry weight shown and dry weight used for $\mathrm{HI}$ are different because the seed weight was highest on a date other than the last. 


\section{Table 4}

Nutrient values from Delmarva and North Dakota. Nitrogen $(\mathrm{N})$ was measured in 2017. Phosphorus $(P)$ was measured in 2015 to 2016 . Repro is the entire reproductive structure.

\begin{tabular}{|c|c|c|c|c|c|c|c|}
\hline \multirow[b]{2}{*}{ Species } & \multirow[b]{2}{*}{ Plant part } & \multicolumn{2}{|c|}{ Date 1} & \multicolumn{2}{|c|}{ Date 2} & \multicolumn{2}{|c|}{ Date 3} \\
\hline & & $\mathbf{N}(\%)$ & $\left.P\left(g^{g}\right)^{-1}\right)$ & $\mathbf{N}(\%)$ & $P\left(g^{-1}\right)$ & $\mathbf{N}(\%)$ & $P\left(g^{-1}\right)$ \\
\hline \multicolumn{8}{|l|}{ Rushes and sedges } \\
\hline \multirow[t]{2}{*}{ Hardstem bulrush } & Leaves & 1.89 & 0.0020 & 1.35 & 0.0018 & 1.30 & 0.0015 \\
\hline & Repro & - & 0.0029 & 1.43 & 0.0032 & 0.74 & 0.0024 \\
\hline \multirow[t]{2}{*}{ Slough sedge } & Leaves & 2.78 & 0.0043 & 1.81 & 0.0032 & 1.28 & 0.0025 \\
\hline & Repro & - & - & - & - & - & 0.0030 \\
\hline \multirow[t]{2}{*}{ Poverty rush } & Leaves & 0.64 & 0.0019 & 0.74 & 0.0013 & 0.94 & 0.0011 \\
\hline & Repro & 1.02 & 0.0019 & 0.73 & 0.0022 & 0.70 & 0.0008 \\
\hline \multirow[t]{2}{*}{ Marsh flatsedge } & Leaves & 2.48 & 0.0020 & 1.05 & 0.0017 & 0.62 & 0.0005 \\
\hline & Repro & 1.83 & 0.0025 & 1.50 & 0.0018 & 1.14 & - \\
\hline \multirow[t]{2}{*}{ Average } & Leaves & 1.95 & 0.0026 & 1.24 & 0.0020 & 1.04 & 0.0014 \\
\hline & Repro & 1.43 & 0.0024 & 1.22 & 0.0024 & 0.86 & 0.0021 \\
\hline \multicolumn{8}{|l|}{ Forbs } \\
\hline \multirow[t]{2}{*}{ Narrowleaf cattail } & Leaves & 1.75 & 0.0031 & 1.08 & 0.0026 & 1.40 & 0.0018 \\
\hline & Repro & - & - & 0.68 & 0.0031 & 1.60 & 0.0027 \\
\hline \multirow[t]{3}{*}{ Smartweed } & Leaves & 1.35 & 0.0032 & 2.41 & 0.0025 & 2.12 & 0.0022 \\
\hline & Stems & 1.00 & 0.0029 & 1.02 & 0.0025 & 0.77 & 0.0021 \\
\hline & Repro & - & - & - & - & 1.40 & 0.0032 \\
\hline \multirow[t]{3}{*}{ Average } & Leaves & 1.55 & 0.0031 & 1.75 & 0.0025 & 1.76 & 0.0020 \\
\hline & Stems & 1.00 & 0.0029 & 1.02 & 0.0025 & 0.77 & 0.0021 \\
\hline & Repro & - & - & 0.68 & 0.0031 & 1.50 & 0.0030 \\
\hline \multicolumn{8}{|l|}{ Grasses } \\
\hline \multirow[t]{2}{*}{ Reed canarygrass } & Leaves & 3.10 & 0.0044 & 2.12 & 0.0038 & 1.00 & 0.0022 \\
\hline & Repro & - & - & 1.61 & 0.0064 & 1.10 & 0.0038 \\
\hline \multirow[t]{2}{*}{ Sprangletop } & Leaves & 1.73 & 0.0044 & 1.45 & 0.0027 & 1.70 & 0.0016 \\
\hline & Repro & - & - & 1.41 & 0.0023 & 1.50 & - \\
\hline \multirow[t]{2}{*}{ Average } & Leaves & 2.42 & 0.0044 & 1.79 & 0.0033 & 1.35 & 0.0019 \\
\hline & Repro & - & - & 1.51 & 0.0043 & 1.30 & 0.0038 \\
\hline
\end{tabular}

in the season, some had no stems, and as such all plant parts were treated as leaves. With these yields and updated parameters, we were able to perform model simulations.

ALMANAC Simulations. Simulation results closely resembled measured values. Though we have data for five sites, five years, and 18 species, only sites and species with the most complete data were used. We simulated 10 species at one to three sites, and three functional groups at two to three sites. Plant parameters for multisite species were consistent except for population (POP) and degree days from planting to maturity (PHU), which were adjusted for sites (table 5). The parameters used were derived from data from sites and years, not just from the simulated sites. Functional groups were from this 2013 to 2017 data, but some plant parameters were changed based on the values of simulated species used for the group. For example, six species were originally in the forbs group, but we only simulated two of them, so we changed a few values based on those simulations. If WA is higher than measured it was because WA includes roots and our measurements were based only on aboveground biomass. If DMLA is higher than measured it was because we wanted to make sure real Max LAI was reached by the harvest date. If HMX is higher than measured it was because we used values from the literature.

The ALMANAC yields were consistently similar to the measured yields (table 6) by plant species and site. ALMANAC simulated yields within $0 \%$ to $6 \%$ for single site species. Multisite species simulations showed greater discrepancies from measured values. These yields were within $1 \%$ to $37 \%$ of measured yields. These multisite species were measured at more sites than were simulated, which likely accounts for the large differences in numbers. At each site for the multisite species, values were within $0 \%$ to $7 \%$ of measured values at the site as opposed to the measured average (data not shown). The functional group ALMANAC yields were within 5\% of the measured yields (table 7). The rushes and sedges and forbs functional groups were simulated at all three sites using data from all species, all five years, and all five sites. The grasses functional group was simulated at North Dakota and California using data from those two sites from all five years and 6 species. Comparisons between all the simulated and measured yields had an $r^{2}$ value greater than 0.99 (figure 2). Comparisons with multisite values instead of single sites had an $r^{2}$ value of 0.95 (figure 3). ALMANAC simulated the single site yields of multisite plants more closely than a multisite average.

\section{Summary and Conclusions}

Wetland models are critical for informed wetland management and policy at multiple spatial and temporal scales, especially in light of land cover and climate change. With increased knowledge of the environmental effects of specific practices, conservation efforts could be more effectively implemented. This study is an important advancement of the CEAP-Wetlands efforts. These field data and resulting model simulations are essential first steps to being able to answer many of the questions CEAPWetlands has been charged with. These questions include what difference are wetlands making, what practices have the greatest impact, where is support needed, and what effect do changes to the uplands have on wetlands. By successfully simulating wetland plant functional groups, we can now use these groups in landscape simulations to better incorporate wetlands in scenarios of interest, e.g., climate change, land use change, and conservation effort assessments. We now have reasonable parameters for the appropriate type of plants to simulate. These parameters for freshwater wetlands in the United States are a good starting point for other researchers to further test this methodology. These parameters, along with the new parameters for black willow (Salix nigra) and green ash (Fraxinus pennsylvanica) (Kim et al. 2018a), allow for more informed simulations of wetlands. This paper along with the one by Kim et al. (2018a) show the beginning of our modeling capabilities with the incorporation of validated wetland plant ALMANAC 


\section{Table 5}

Parameters simulated from 2013 to 2017 data. WA is radiation use efficiency (RUE) for the model calculated as RUE times 10 as a unit conversion factor. $\mathrm{HI}$ is harvest index. TB is maximum growing temperature in ${ }^{\circ} \mathrm{C}$. TG is minimum growing temperature in ${ }^{\circ} \mathrm{C}$. DMLA is maximum leaf area index (LAI). DLAI is the fraction of the growing season when leaf area declines. LAP1 is the first point on leaf area development curve, and LAP2 is the second point. PPL1 is the plant population at a low density with a fraction of maximum potential LAl, and PPL2 is the number at a higher density. RBMD is the rate of decline in WA. HMX is the maximum plant height in meters. RDMX is the maximum root depth in meters. EXT is the extinction coefficient from Beer's law. POP is the plant population per $1 \mathrm{~m}^{2}$. PHU is the potential heat units.

\begin{tabular}{|c|c|c|c|c|c|c|c|c|c|c|c|c|c|c|c|c|}
\hline Species & WA & HI & TB & TG & DMLA & DLAI & LAP1 & LAP2 & PPL1 & PPL2 & RBMD & HMX & RDMX & EXT & POP & PHU \\
\hline Bulrush & $54 \dagger$ & 0.13 & 30 & 10 & $2.8 \dagger$ & 0.6 & 15.13 & 75.99 & 5.12 & 20.96 & 0.1 & $2.99 \dagger$ & 0.36 & 0.8 & 9 & 780 \\
\hline BulrushCA & $41 \dagger$ & 0.13 & 30 & 10 & $2.8 \dagger$ & 0.2 & 17.13 & 18.99 & 5.12 & 20.96 & 1 & $2.99 \dagger$ & 0.36 & 0.8 & 20 & 1,000 \\
\hline Cattail* & $50 \dagger$ & 0.2 & 30 & 10 & $4 \dagger$ & 0.74 & 16.51 & 75.99 & 1.12 & 10.9 & 0.1 & 2.04 & 0.36 & 0.7 & $\begin{array}{l}6.7 \\
4 ; \\
10\end{array}$ & $\begin{array}{r}825 \\
865 \\
1,000\end{array}$ \\
\hline Smartweed* & $18 \dagger$ & 0.03 & 27 & 10 & $2.2 \dagger$ & 0.6 & 17.25 & 60.73 & 3.12 & 15.96 & 0.1 & $1.2 \dagger$ & 0.36 & 1.15 & $\begin{array}{c}17 \\
8\end{array}$ & $\begin{array}{l}700 \\
900\end{array}$ \\
\hline Reed canarygrass & $22 \dagger$ & 0.12 & 25 & 3 & 2.84 & 0.5 & 13.17 & 36.99 & 1.12 & 6.96 & 0.1 & 1.89 & 0.36 & 0.75 & 9 & 1,600 \\
\hline Sprangletop & 21.35 & 0.07 & 25 & 12 & 1.61 & 0.4 & 13.31 & 58.99 & 1.12 & 6.96 & 0.1 & $1.49 \dagger$ & 0.41 & 1.26 & 9 & 1,600 \\
\hline Marsh flatsedge & $20 \dagger$ & 0.3 & 25 & 12 & $1.3 \dagger$ & 0.7 & 3.4 & 73.6 & 3.12 & 20.96 & 0.1 & 0.83 & 0.25 & 1.27 & 9 & 1,100 \\
\hline Poverty rush & 96.01 & 0.16 & 25 & 12 & 4.31 & 0.4 & 3.18 & 33.99 & 1.12 & 6.96 & 3 & 1.61 & 0.15 & 0.48 & 8 & 800 \\
\hline Joint grass & $16 \dagger$ & 0.07 & 25 & 10 & 5.45 & 0.65 & 38.74 & 51.99 & 1.12 & 6.96 & 0.1 & 0.8 & 0.10 & 0.68 & 8 & 1,300 \\
\hline Watergrass & $20 \dagger$ & 0.11 & 25 & 10 & 2.65 & 0.8 & 8.57 & 99.99 & 1.12 & 25.96 & 0.1 & 1.5 & 0.36 & 0.55 & 30 & 1,700 \\
\hline Swamp timothy & 19.12 & 0.2 & 25 & 12 & 3.44 & 0.4 & 69.62 & 80.67 & 1.12 & 6.96 & 0.1 & 0.75 & 0.36 & 1 & 10 & 1,300 \\
\hline Rushes/sedges & 33.36 & 0.19 & 25 & 12 & 1.9 & 0.4 & $9.12 \ddagger$ & $50.75 \ddagger$ & $4.12 \ddagger$ & $17.96 \ddagger$ & $0.5 \ddagger$ & 1.59 & 0.20 & 0.76 & 20 & 900 \\
\hline Forbs & 26.95 & 0.11 & 25 & 12 & 1.38 & 0.4 & $17.38 \ddagger$ & $68.86 \ddagger$ & $2.12 \ddagger$ & $13.93 \ddagger$ & 0.1 & 1.01 & 0.36 & 0.7 & 16 & 900 \\
\hline Grasses & 19.694‡ & $0.11 \neq$ & 25 & $9.4 \ddagger$ & $3.2 \ddagger$ & $0.55 \ddagger$ & $28.48 \ddagger$ & $65.93 \ddagger$ & 1.12 & 6.96 & 0.1 & 1.16 & 0.28 & 0.75 & 9 & 1,500 \\
\hline
\end{tabular}

*Cattail and smartweed have different values for POP and PHU based on location. The numbers listed are for North Dakota first, followed by Delmarva, then California, if applicable.

†These parameters were higher than measured values.

‡Functional group parameters from simulated species instead of calculated values.

\section{Table 6}

Comparing yields simulated by the ALMANAC model (ALNC yield) and measured yields (MSRD yield). ALNC/MSRD is the ratio of simulated yields divided by measured yields. These data are for sites where the plant species were measured and simulated. Plants belonging to the functional group rushes/sedges are depicted with symbol ${ }^{\mathrm{R}}$, other forbs are shown with $\mathrm{F}$, and grasses have symbol ${ }^{G}$. The average measured values for multisite species includes sites we did not simulate.

\begin{tabular}{lllll}
\hline Species & ALNC yield & MSRD yield & ALNC/MSRD & Sites \\
\hline Reed canarygrass $^{G}$ & 5.15 & 5.08 & 1.01 & North Dakota \\
Sprangletop $^{G}$ & 3.22 & 3.23 & 1.00 & North Dakota \\
Marsh flatsedge $^{R}$ & 0.91 & 0.97 & 0.94 & Maryland \\
Poverty rush $^{R}$ & 7.07 & 6.88 & 1.03 & Maryland \\
Joint grass $^{G}$ & 4.34 & 4.47 & 0.97 & California \\
Watergrass $^{G}$ & 7.31 & 7.74 & 0.94 & California \\
Swamp timothy $^{G}$ & 6.39 & 6.48 & 0.99 & California \\
Bulrush $^{R}$ & 5.58 & 4.06 & 1.37 & North Dakota, California \\
Cattail $^{\mathrm{F}}$ & 8.91 & 8.95 & 0.99 & North Dakota, Maryland, \\
Smartweed & & & & California \\
& 2.17 & 2.77 & 0.78 & North Dakota, Maryland \\
& & & &
\end{tabular}




\section{Table 7}

Comparing functional groups' simulated and measured yields. Functional group species are in tables 2 and 4 . Table 2 shows all species in the measured group, and table 4 shows which species we simulated. Functional groups' measured average includes plants we did not simulate. ALNC stands for ALMANAC. MSRD stands for measured. ALNC/MSRD is the ratio of simulated yields divided by measured yields. $N$ stands for the number of sites or species measured.

\begin{tabular}{llllll}
\hline Functional groups & $\begin{array}{l}\text { ALNC } \\
\text { all sites }\end{array}$ & $\begin{array}{l}\text { MSRD } \\
\text { all sites }\end{array}$ & ALNC/MSRD & $\begin{array}{l}\boldsymbol{N} \text { sites } \\
\text { measured }\end{array}$ & $\begin{array}{l}\boldsymbol{N} \text { species } \\
\text { measured }\end{array}$ \\
\hline Rushes/sedges & 4.02 & 3.85 & 1.05 & 5 & 5 \\
Forbs & 3.07 & 3.16 & 0.97 & 5 & 6 \\
Grasses & 4.82 & 5.09 & 0.95 & 2 & 6
\end{tabular}

\section{Figure 2}

Comparing measured and simulated plant yields for all data using singles site runs, runs of individual sites of the multisite species, and runs for the functional groups.

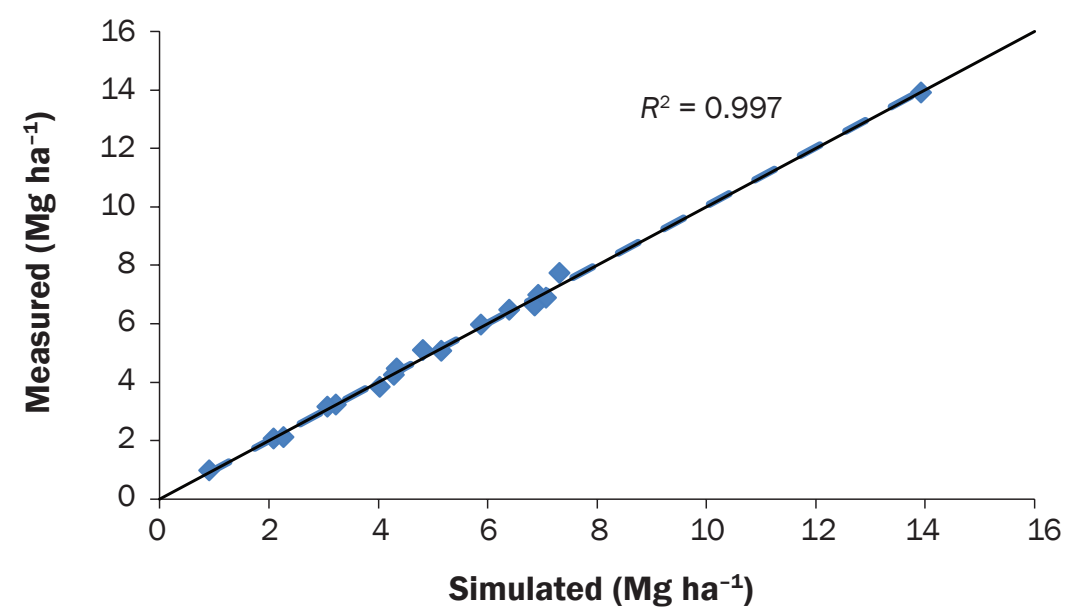

\section{Figure 3}

Comparing measured and simulated plant yields just as in figure 2 , but using multisite species average value instead of runs from each site of the multisite species.

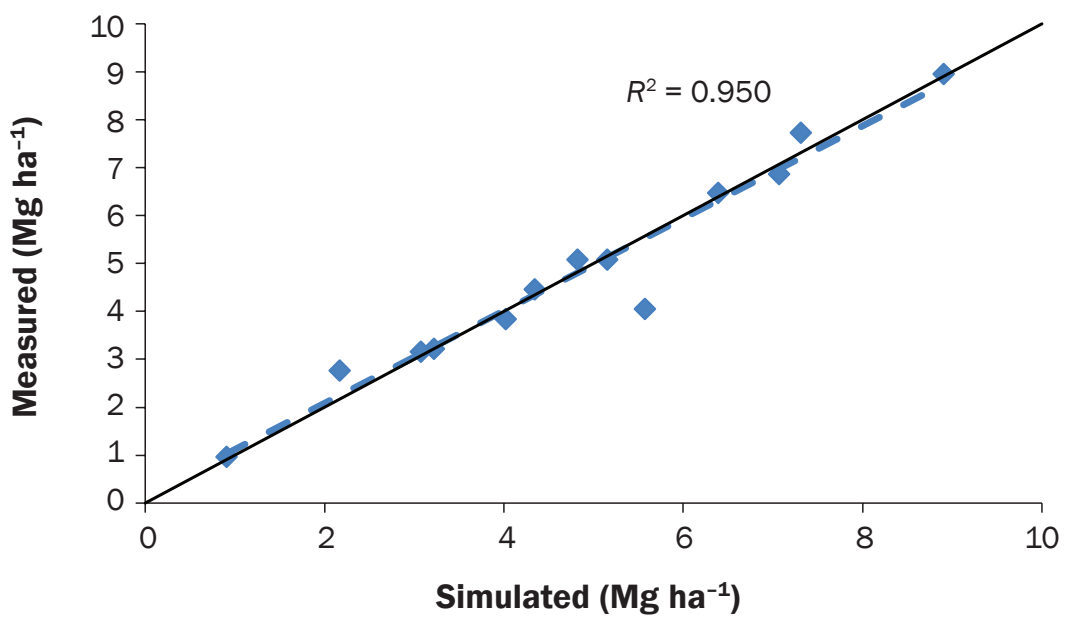

descriptive purposes only and does not imply endorsement by the US Government.

\section{References}

Atwood, J.D., D. Moffitt, M.L. Norfleet, A.D. King, and J. Lemunyon. 2009. Transforming Survey Data to APEX Model Input Files. USDA NRCS Report. Washington, DC: USDA Natural Resources Conservation Service.

Boer, M., and M. Stafford Smith. 2003. A plant functional approach to the prediction of changes in Australian rangeland vegetation under grazing and fire. Journal of Vegetation Science 14:333-344.

Brauman, K.A., G.C. Daily,T.K. e. Duarte, and H.A. Mooney. 2007. The nature and value of ecosystem services: An overview highlighting hydrologic services. Annual Review of Environment and Resources 32:67-98.

Byun, C., S. de Blois, J. Brisson, and W. Cornwell. 2013. Plant functional group identity and diversity determine biotic resistance to invasion by an exotic grass. Journal of Ecology 101:128-139.

Chavez, J.C., J. Enciso, M.N. Meki, J. Jeong, and V.P. Singh. 2018. Simulation of energy sorghum under limited irrigation levels using the EPIC model. Transactions of the ASABE 61:121-131.

Esralew, R.A., L. Flint, J.H.Thorne, R. Boynton, and A. Flint. 2016. A framework for effective use of hydroclimate models in climate-change adaptation planning for managed habitats with limited hydrologic response data. Environmental Management 58:60-75.

Euliss Jr., N.H., L.M. Smith, S. Liu, M. Feng, D.M. Mushet, R.F. Auch, and T.R. Loveland. 2010. The need for simultaneous evaluation of ecosystem services and land use change. Environmental Science and Technology 44:7761-7763

Gordon, L.J., C.M. Finlayson, and M. Falkenmark. 2010. Managing water in agriculture for food production and other ecosystem services. Agricultural Water Management 97:512-519.

Guo, T., B.A. Engel, G. Shao, J.G. Arnold, R. Srinivasan, and J.R. Kiniry. 2015. Functional approach to simulating short-rotation woody crops in process-based models. BioEnergy Research 8:1598-1613.

Isaac, R.,W. Johnson, andY. Kalra. 1998. Elemental determination by inductively coupled plasma atomic emission spectrometry, 165-170. In Handbook and Reference Methods for Plant Analysis. New York: CRC Press.

Johnson, M.V.V., M.L. Norfleet, J.D. Atwood, K.D. Behrman, J.R. Kiniry,J.G.Arnold, M.J.White, and J.Williams. 2015. The Conservation Effects Assessment Project (CEAP):A national scale natural resources and conservation needs assessment and decision support tool. IOP Conference Series: Earth and Environmental Science 25:012012.

Kim, S.M., J. Jeong, D. Keesee, and J.R. Kiniry. 2018b. Development, growth, and biomass simulations of two common wetland tree species in Texas. Environmental Monitoring and Assessment 190: 521. 
Kim, S., J. Jeong, and J.R. Kiniry. 2018a. Simulating the productivity of desert woody shrubs in southwestern Texas. In Arid Environments and Sustainability. DOI:10.5772/intechopen.73703.

Kiniry, J.R., J. Briggs, J. Englert, M. Weltz, K. Jensen, D. Tilley, M. Stannard, A. Young-Mathews, T. Blanke, M. Smither-Kopperl, S. Winslow, and D. Goodson. 2014. Plant parameters for plant functional groups of western rangelands to enable process-based simulation modeling. American Journal of Experimental Agriculture 4:746-766.

Kiniry, J.R., B.L. Burson, G.W. Evers, J.R. Williams, H. Sanchez, C. Wade, J.W. Featherston, and J. Greenwade. 2007. Coastal bermudagrass, bahiagrass, and native range simulation at diverse sites in Texas. Agronomy Journal 99.

Kiniry, J.R., M.V.V. Johnson, B.C. Venuto, and B.L. Burson. 2013. Novel application of ALMANAC: Modelling a functional group, exotic warm-season perennial grasses. American Journal of Experimental Agriculture 3:631-650

Kiniry, J.R., S. Kim, A.S. Williams, T.R. Lock, and R.L. Kallenbach. 2018. Simulating bimodal tall fescue growth with a degree-day-based process-oriented plant model. Grass and Forage Science https://doi.org/10.1111/ gfs. 12346.

Kiniry, J.R., J.M. Muscha, M.K. Petersen, R.W. Kilian, and L.J. Metz. 2017. Short duration, perennial grasses in low rainfall site in Montana deriving growth parameters and simulating with a process-based model. Journal of Experimental Agriculture International 15:1-13.

Kiniry, J.R., J.R. Williams, P.W. Gassman, and P. Debaeke. 1992. General process-oriented model for two competing plant species. Transactions of the ASAE 35:801-810.

Liu, Y., W. Yang, H. Shao, Z. Yu, and J. Lindsay. 2018. Development of an integrated modelling system for evaluating water quantity and quality effects of individual wetlands in an agricultural watershed. Water 10.

Matchett, E.L., and J.P. Fleskes. 2017. Projected impacts of climate, urbanization, water management, and wetland restoration on waterbird habitat in California's Central Valley. PLoS One 12: e0169780.

Meki, M.N., J.R. Kiniry, A.H. Youkhana, S.E. Crow, R.M. Ogoshi, M.H. Nakahata, R. Tirado-Corbalá, R.G. Anderson, J. Osorio, and J. Jeong. 2015. Two-year growth cycle sugarcane crop parameter attributes and their application in modeling. Agronomy Journal 107:1310.

Meki, M.N., R.M. Ogoshi, J.R. Kiniry, S.E. Crow, A.H. Youkhana, M.H. Nakahata, and K. Littlejohn. 2017. Performance evaluation of biomass sorghum in Hawaii and Texas. Industrial Crops and Products 103:257-266.

Monsi, M., and T. Saeki. 1953. The light factor in plant communities and its significance for dry matter production. Japanese Journal of Botany 14:22-52.

Muler, A.L., C.A. Canham, E.J.B. van Etten, W.D. Stock, and R.H.Froend. 2018. Using a functional ecology approach to assist plant selection for restoration of Mediterranean woodlands. Forest Ecology and Management 424:1-10.

NOAA (National Oceanic and Atmospheric Administration).

2018. Climate Data Online Search. Asheville, NC: US National Centers for Environmental Information. http://ncdc.noaa.gov/cdo-web/search.

Osorio, J., J. Jeong, K. Bieger, and J. Arnold. 2014. Influence of potential evapotranspiration on the water balance of sugarcane fields in Maui, Hawaii. Journal of Water Resource and Protection 06:852-868.

Pattison-Williams, J.K., J.W. Pomeroy, P. Badiou, and S Gabor. 2018. Wetlands, flood control and ecosystem services in the Smith Creek Drainage Basin: A case study in Saskatchewan, Canada. Ecological Economics 147:36-47.

Pokorny, M.L., R.L. Sheley, C.A. Zabinski, R.E. Engel, T.J. Svejcar, and J.J. Borkowski. 2005. Plant functional group diversity as a mechanism for invasion reisitance. Restoration Ecology 13:448-459.

Potter, S.R., S. Andrews, J.D. Atwood, R.L. Kellogg, J Lemunyon, L. Norfleet, and D. Oman. 2006. Model Simulation of Soil Loss, Nutrient Loss, and Change in Soil Organic Carbon Associated with Crop Production. USDA NRCS Report. Washington, DC: USDA Natural Resources Conservation Service.

Rezaeianzadeh, M., L. Kalin, and M. Hantush. 2018. An integrated approach for modeling wetland water level: Application to a headwater wetland in coastal Alabama, USA. Water 10 .

Scanlon, B.R., R.C. Reedy, D.A. Stonestrom, D.E. Prudic, and K.F. Dennehy. 2005. Impact of land use and land cover change on groundwater recharge and quality in the southwestern US. Global Change Biology 11:1577-1593.

Schilling, K.E., and J.R. Kiniry. 2007. Estimation of evapotranspiration by reed canarygrass using field observations and model simulations. Journal of Hydrology 337:356-363

Sizo, A., B. Noble, and S. Bell. 2015. Futures analysis of urban land use and wetland change in Saskatoon, Canada: An application in strategic environmental assessment. Sustainability 7:811-830

Smith, L.M., W.R. Effland, K.D. Behrman, and M.-V.V Johnson. 2015. Assessing the effects of USDA conservation programs on ecosystem services provided by wetlands. National Wetlands Newsletter 37:10-14.

Smith, W.D., G.L. Rollins, and R. Shinn. 1995. A Guide to Wetland Habitat Management in the Central Valley. Sacramento, CA: California Department of Fish and Game. US Fish and Wildlife Service. 2009. Sacramento, Delevan, Colusa, and Sutter National Wildlife Refuges Final Comprehensive Conservation Plan and Environmental Assessment.Washington, DC: US Fish and Wildlife Service Pacific Southwest Region Refuge Planning Office and Sacramento National Wildlife Refuge Complex.

USDA NRCS (Natural Resources Conservation Service) 2014. Water Quality Effects and Placement of Pasture
BMPs in the Spring Creek Watershed (Centre County, PA). USDA NRCS Science Note. Washington, DC: USDA Natural Resources Conservation Service.

USDA NRCS. 2018a. Estimating the Effects of Wetland Conservation Practices in Croplands Approaches for Modeling in the CEAP-Cropland Assessment. USDA NRCS Science Note. Washington, DC: USDA Natural Resources Conservation Service.

USDA NRCS. 2018b. The PLANTS Database. National Plant Data Team, Greensboro, NC 27401-4901 USA. Washington, DC: USDA Natural Resources Conservation Service. http://plants.usda.gov.

USDA NRCS. 2018c. Soil Survey Staff, Web Soil Survey. Washington, DC:USDA Natural Resources Conservation Service. http://websoilsurvey.nrcs.usda.gov.

Visser, J., and S. Duke-Sylvester. 2017. LaVegMod v2: Modeling coastal vegetation dynamics in response to proposed coastal restoration and protection projects in Louisiana, USA. Sustainability 9.

Voldseth, R.A., W.C. Johnson, T. Gilmanov, G.R Guntenspergen, and B.V. Millett. 2007. Model estimation of land-use effects on water levels of northern prairie wetlands. Ecological Applications 17:527-540.

Wang, X., P. Gassman, J. Williams, S. Potter, and A. Kemanian. 2008. Modeling the impacts of soil management practices on runoff, sediment yield, maize productivity, and soil organic carbon using APEX. Soil and Tillage Research 101:78-88.

Wang, E., C. Xin, J.R. Williams, and C. Xu. 2006. Predicting soil erosion for alternative land uses. Journal of Environmental Quality 35:459-67.

Williams, A.S., J.R. Kiniry, D. Mushet, L.M. Smith, S. McMurry, K. Attebury, M. Lang, G.W. McCarty, J.A Shaffer, W.R. Effland, and M.-V.V. Johnson. 2017. Model parameters for representative wetland plant functional groups. Ecosphere 8 .

Wolski, P., and M. Murray-Hudson. 2008. 'Alternative futures' of the Okavango Delta simulated by a suite of global climate and hydro-ecological models. Water SA 34:605-610. 